\title{
GENERALIZATION AND CHARACTERIZATION IN SOPHOCLES' TRACHINIAE AND ANTIGONE
}

\author{
LUCY VAN ESSEN-FISHMAN
}

I N MOMENTS OF TENSION, many tragic figures are driven to generalization. This tendency, on the part of both characters and chorus, has long been recognized as a distinctive part of Greek tragic style and continues to be a subject of interest; near the beginning of A. E. Housman's "Fragment of a Greek Tragedy," Alcmaeon replies to a choral question with the gnomic "Not all that men desire do they obtain," and, much more recently and seriously, Richard Martin and R. B. Rutherford have both discussed the prevalence of generalizations and proverbial speech in ancient drama. ${ }^{1}$ While Housman's use of general statements in his parody suggests that tragic generalizations are, at best, delaying tactics for characters and, at worst, meaningless ways to fill out a line of verse, the characters of Greek tragedy typically generalize under particular circumstances and for particular reasons. Moreover, tragic figures vary in their use of general statements, and both the ideas which a character chooses to express as general truths and the circumstances under which that character resorts to generality can give us a great deal of information about that character's place in the world of the play.

The role of general statements in various genres of Greek literature has attracted a good deal of attention over the last twenty years. André Lardinois, in particular, has advanced the idea that the gnomic statements that occur in Greek poetry - particularly in the Homeric poems, but also in tragedy — can fruitfully be studied in terms of their relationship to the proverbial expressions that have been observed in many cultures around the world and throughout history. By looking to twentieth-century sociolinguistics as a framework for viewing archaic Greek gnomai, Lardinois has been able to use the context in which Greek gnomic statements are delivered as a tool for interpreting their implications. ${ }^{2}$ Who utters a general statement is an important factor; in his study of general statements as indicators of character in the Iliad, Lardinois notes that a gnomic statement delivered to an equal is a very different rhetorical device than the same statement might be if it were delivered to a person of inferior social standing. Given that speaking in gnomai can have marked implications for the relationships between different figures, Lardinois has convincingly argued that gnomic speech in Homer can be an important mark of character. ${ }^{3}$

1. Housman 1928, 414; Martin 2009; Rutherford 2012, 365-98.

2. Lardinois $1997 ; 2000 ; 2001 ; 2006$.

3. Lardinois 2000,642 and throughout. 
In a similar way, the gnomic statements delivered by tragic characters can illuminate aspects of the general social order that exists within a play as well as the different personalities of the individual figures who speak in gnomai. Tragic gnomai, like Homeric ones, have a pronounced social aspect, inasmuch as gnomic statements in tragedy imply certain shared assumptions about the world, which enable characters to interpret gnomai appropriately; since tragic gnomai typically contain implicit commands or advice, they also depend on some degree of established social order, according to which individual characters have the right to speak in general terms. ${ }^{4}$ Although gnomai are always connected to social order, different characters negotiate the conventions of speaking in gnomai differently, and their use of gnomic speech can be an important aspect of their selfpresentation. How characters respond to one another's generalizations can also vary considerably, and whether - and by whom - a particular character is accepted as a speaker of gnomai can shape her interaction with other figures in the play.

As well as providing a framework for interpreting characters and their places in the social order of a play, gnomic statements are also speech acts that can, depending on the circumstances under which they are uttered, allow characters to achieve a variety of rhetorical goals. ${ }^{5}$ Although a gnomic statement such as Hae-

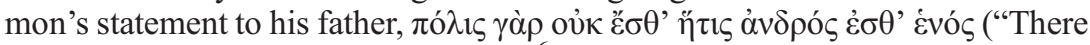
is no city which belongs to one man," "Soph. Ant. 737), is not a performative utterance in the same way that making a promise would be, speaking in gnomai nevertheless allows Haemon "to do things with words" on several important levels. $^{7}$ On the one hand, Haemon's statement is an attempt to get Creon to do something; by making a general statement about the communal nature of cities, Haemon implicitly directs Creon to act in accordance with this general statement and remember the needs of others in Thebes, and his gnome can therefore be seen to be related to the category of speech acts that John Searle classifies as "directives." 8 Perhaps more importantly, by making a statement that can be taken as a command, Haemon implies that he has the authority to make such a command; although Haemon may not have his father's level of civic authority, his speech is just as authoritative as Creon's, and speaking gnomically allows Haemon to perform the authority that he wishes to have recognized. Different Sophoclean characters use gnomic statements to different effect, depending on their individual circumstances; some, as Creon does, use general statements to bolster an already authoritative position, while others, like Haemon, generalize in an effort to suggest that they deserve the respect associated with gnomic speech.

4. Seitel 1981, 126-28; Foley 1994, 89. These social aspects of gnomic or proverbial speech will be discussed in greater detail below. Searle $(1969,64-65)$ argues that there are certain "preparatory conditions" that must be met for a speech act to be successful. See also Searle 1976, 5.

5. Searle $(1969,23)$ notes, "the production or issuance of a sentence token under certain conditions is a speech act."

6. All translations are my own.

7. Austin 1975, 4-7 contains Austin's preliminary definition of performative utterances, according to which Haemon's gnome would not count as performative.

8. Searle $(1976,10-11)$ draws a distinction between "representatives" and "directives" as different categories of speech act; although Haemon's gnome is outwardly what Searle would classify as a representative statement, it nevertheless has some of the illocutionary force of a directive. 
In this article, I will be arguing that the ways in which individual Sophoclean characters deploy generalizations often shed light upon how those characters position themselves in relation to the rest of the dramatic world. After an introductory discussion of the wider importance of gnomai as speech acts that help to establish and maintain authority and the particular questions raised by generalizations in dramatic contexts, I will look in detail at the individual ways in which two very different Sophoclean characters generalize. Both Deianeira in Trachiniae and Creon in Antigone are heavily reliant on generalizations: Deianeira delivers ten general statements of her own after rejecting the proverb with which she begins her first speech, while the Creon of Antigone has been said to be the most prolific generalizer in Sophocles. ${ }^{9}$ For both Deianeira and Creon, gnomic speech is closely connected to authority, but the two characters deliver generalizations under different circumstances and to very different effects. For Deianeira, who throughout Trachiniae works to maintain control of an increasingly tenuous domestic situation, gnomai are a means of working through problems and providing a level of self-justification; Creon's gnomai, on the other hand, are for the most part ostensibly outward looking, a set of rhetorical tools designed to bolster his authority over his own household and over all of Thebes.

\section{GENERALIZING, IN AND OUT OF DRAMA}

In discussing the generalizations or gnomai delivered by Sophoclean characters, I will be using those terms to refer to statements of broadly applicable truth; gnomai are typically linked to the specific circumstances under which they are spoken, but, as Aristotle suggests in the Rhetoric, their speakers nevertheless suggest that their words can be applied more generally, whether in equivalent situations or in other situations that happen to involve equivalent figures. ${ }^{10}$ The subjects of such statements are therefore indefinite: most general statements concern "a man," a generalized second-person subject, or an abstraction such as "the divine" or "truth" or "justice." In addition to their broad applicability, the general statements discussed in this article are all relatively self-contained; although they are often delivered in series, individual gnomai spoken by Sophoclean characters very rarely stretch over more than two or three lines. ${ }^{11}$

Although many definitions link gnomai with proverbs, and although proverbs typically fall under the category of "statements of broadly applicable truth" which I mentioned above, I will — with a few notable exceptions — be avoiding the term "proverb" in my analysis of gnomic statements in Sophocles. ${ }^{12}$ Proverbs

9. Wolf $(1910,48)$ identifies Creon as the most prolific generalizer in Sophocles; Kitzinger $(1976,144)$ comments on the number of generalities that Creon issues, identifying twenty-five in 350 lines of text. Cf. also Podlecki 1966, 362; Foley 2001, 184-85.

10. Aristotle comments, "A gnome is a statement, not about particulars, such as what sort of person Iphicrates was, but generally applicable," and goes on to specify further that gnomai deal with how one should or should not act (Rh. 1394a21-25).

11. Brevity is often identified as a feature of such general statements; Abrahams $(1972,120)$ notes that most proverbs fit in a single line of "folk verse." The general statement at Soph. Trach. 144-50 far exceeds this typical length, and will be discussed further below.

12. In this way my use of terminology diverges somewhat from that of Aristotle, who states that "some proverbs [Ěvııı $\tau \tilde{\omega} v \pi \alpha \rho \circ \mu 1 \tilde{\omega} v]$ are also gnomai" (Rh. 1395a18). Cf. Kindstrand 1978, 74 on why Aristotle classes only some proverbs as gnomai. 
are marked by a traditional element that is not a characteristic of all gnomic speech; to call a statement a proverb is to imply that it has been handed down in roughly the same form through multiple speakers or writers over an extended period of time. ${ }^{13}$ Sophoclean gnomai, on the other hand, although they often have a formal resemblance to proverbs and may sometimes have roots in traditional wisdom, can only rarely be firmly identified as traditional. Nevertheless, since gnomai and proverbs are often deployed under similar circumstances and to similar effect, and since a considerable body of scholarship exists on the use of proverbs, both in ancient Greek literature and in the literature and society of other cultures, I will be drawing on this scholarship in order to support some of my arguments about the use of Sophoclean gnomai. ${ }^{14}$

As speech acts, both proverbs and gnomic statements in general can be classified according to Searle's taxonomy as "representatives," that is, statements in which the speaker commits herself to the truth of an assertion. ${ }^{15}$ At the same time, both proverbs and the not necessarily traditional gnomai with which I will primarily be concerned typically contain implicit instructions concerning what ought to be done in a given situation, and this element of advice suggests that general statements can just as usefully be described in Searle's terminology as "commissives" or "directives," that is, speech acts that suggest a course of action. ${ }^{16}$ The advice contained within a gnomic statement can be directed at different figures depending on the circumstances under which the statement is made, and Peter Seitel has borrowed the grammatical terms "first-person," "secondperson," and "third-person" to describe the intended recipient of a piece of proverbial wisdom; a "first-person" use of a proverb includes advice for the speaker herself, a "second-person" proverb suggests a course of action for the addressee, and a "third-person" proverb offers advice to some third party, who may or may not be present to hear the proverb. Importantly, these categories are not reliant on the grammatical person used in the proverb, inasmuch as a grammatically identical proverb can be first-, second-, or third-person depending on the circumstances in which it is used, and may in fact be applicable to multiple people; depending on the circumstances, a gnome apparently containing second-person advice for its addressee can often also be taken as a first-person gnome containing guidance for its speaker. Determining the intended recipient of the advice

13. Kindstrand $(1978,77)$ notes that "antiquity and truth" are the defining qualities of Greek proverbs. Proverbs need not be repeated verbatim to count as traditional; Lardinois $(2001,94-95)$ discusses gnomai as "coined with the help of traditional formulae and themes"; see also Slater 2000, 104; Easterling 2009, 162-63.

14. Lardinois (1997) makes a strong case for the application of modern and cross-cultural studies of proverb usage to gnomai in Greek poetry.

15. Searle 1976, 10-11.

16. Seitel $(1981,130)$ discusses proverbs as vehicles for advice. Inasmuch as they are meant to effect a change, gnomai fit into the broad category of speech acts which Searle $(1976,3-4)$ describes as fitting into their context in the "world-to-word" direction. Searle $(1976,11-12)$ divides speech acts that are meant to lead to a course of action into "commissives" and "directives," depending on whether the course of action is to be carried out by the speaker or someone else. In order to preserve the distinction between advice for the addressee and advice for a third party, I will in the following discussion primarily be using Seitel's categorization by person (see below and n. 17); Searle's taxonomy remains important for my purposes insofar as gnomai, as statements that are also commands, requests, or exhortations, fall into multiple categories of speech acts. 
contained within a proverb is thus an important part of making sense of proverbial speech. ${ }^{17}$

As Seitel's distinction between first-, second-, and third-person proverbs suggests, proverbs, and gnomic statements more generally, are speech acts whose impact depends in large part on the implied relationship between a speaker and her listeners. On the one hand, as Searle notes, the relative status of the speaker and listeners can influence the force of any speech act, particularly one in which one party attempts to influence another, ${ }^{18}$ thus the force of the gnomai with which Creon advises Haemon in Antigone differs from the force of those gnomai in which Haemon advises Creon. At the same time, the successful use of a gnomic statement requires a degree of common ground between speaker and listener, and part of learning to be conversant within a culture is learning to understand that culture's socially sanctioned use of proverbs and gnomic speech. ${ }^{19}$ Since gnomai by definition contain few details, their hearers must first have a general awareness of how such statements function, then fill in whatever blanks need to be filled in order to make a particular gnomic statement applicable to the matter at hand, and finally accept that the gnome in question is appropriate under the current circumstances. Gnomai, like proverbs, are spoken with the tacit assumption that their hearers will be able to interpret the statements correctly, and, by making such an assumption, the speaker includes her listeners in an imaginary community defined by shared knowledge. ${ }^{20}$ In this way, when Deianeira generalizes to the chorus of Trachiniae, her generalizations suggest the existence of a certain rapport between herself and her younger companions.

At the same time, the act of speaking in gnomai provides a degree of information about how the speaker wishes to be perceived by her hearers. By tapping into a store of collective wisdom or adopting the speech patterns with which traditional wisdom is often expressed, a speaker makes a claim both to have access to that wisdom, and to be in a position to reinterpret it for others. ${ }^{21} \mathrm{~A}$ hearer with some experience of the typical use of gnomic speech can in turn be expected to know that making gnomic statements is often the prerogative of speakers who have some kind of special authority; although Deianeira's generalizations suggest a degree of confidence in the chorus' ability to interpret her words, they also suggest that Deianeira has a level of understanding that she can impart to the chorus. $^{22}$ This connection between gnomic speech and socially sanctioned wisdom

17. Seitel 1981, 128-29; Lardinois (2000, 643-44) adopts Seitel's categories in classifying the gnomai employed by characters in Homer.

18. Searle 1976,5 .

19. Seitel $(1981,134)$ notes in particular that many cultures have traditional ways of using and explaining proverbs in speech to children, designed to give young members of society the tools which they need to understand proverbs later in life.

20. Foley $(1994,89)$, writing about the role of proverbs in South Slavic epic, observes that both the singer and his audience need to be "fluent in this special register."

21. Abrahams $(1972,122)$ notes that it is "the appearance of collective wisdom" that makes proverbs authoritative, not their actual reliance on tradition. Seitel $(1981,126-28)$ argues that the relationship between speaker and listener is an important element in proverb meaning; Briggs $(1985,800)$ argues that by introducing a proverb, a speaker shifts the locus of authority from herself to the traditional source being cited.

22. See Briggs 1985, 794-95 on the respect given to those who are conversant in traditional wisdom; Abrahams and Babcock $(1977,415)$ define "the primary rule of proverb use in social discourse" as "that they be used only by those who know when and how to employ them appropriately." Martin $(2009,119)$ discusses the performance of proverbs as a way to lay claim to authority. 
exists across cultures and eras; among the Apache, general statements with a traditional form are the exclusive rhetorical property of men and women of advanced years and an established reputation for wisdom and understanding, while Lardinois has observed similarly in his study of characterization through gnomai in the Iliad that second-person gnomai are usually spoken by characters who have a degree of accepted political or moral authority. ${ }^{23}$

Not all speakers of gnomai, however, are unequivocally authoritative. Since speaking gnomically is often associated with wisdom or authority, figures in Homer, tragedy, and elsewhere often speak in gnomai when they need to assert an authority that may not be recognized by all. ${ }^{24}$ The authority of the speaker is a precondition for a successful gnome, and by speaking in gnomai, a speaker can suggest that her authority is an established fact. ${ }^{25}$ Using gnomic speech to assert authority, however, carries a degree of risk; on a rhetorical level, if a gnomic statement is used under the wrong circumstances or by a character who lacks the authority to generalize, both the statement and the advice contained in it are likely to go unheeded. ${ }^{26}$ Perhaps more importantly, inappropriate uses of gnomai - or uses of gnomai that are considered inappropriate - can have consequences for a speaker. A speaker who lacks the socially sanctioned authority to speak gnomically may appear disrespectful if she appropriates the rhetorical strategies of those who are older or more experienced; similarly, a speaker who oversteps her rhetorical bounds may find her authority called into question in ways that it might not have been had she not tried to offer a piece of gnomic advice. ${ }^{27}$ As happens several times in Antigone, rhetorical conflicts over the use of gnomai can spill over into broader personal conflicts between individuals, and, in turn, specific disagreements can lead one person to question another's right to speak in general terms.

When characters in drama generalize, their decision to speak in gnomai raises two sets of questions; although these questions are closely related to those that are raised by gnomic speech in real life, they are complicated by the existence of an offstage audience who may interpret dramatic gnomai in ways that are unavailable both to the direct addressees of those gnomai and to any other characters who may be present onstage. ${ }^{28}$ The first set of questions concerns the identity of the speaker in relation to her onstage listeners: is the speaker the kind of figure who might be expected to speak gnomically? ${ }^{29}$ If she lays claim to a

23. Basso $(1976,99)$ discusses "wise words" among the Apache; Lardinois $(2000,649-50)$ contains a discussion of Nestor's gnomai as a marker of authority. On the widespread use of gnomai in archaic Greek literature and thought, see Versnel 2011, 221-31.

24. Lardinois $(2000,656)$ compares Nestor's use of gnomai in the Iliad to that of Odysseus, who "is not in a natural position of authority in the Greek camp."

25 . Searle $(1976,5)$ discusses the preparatory conditions for giving an order, which apply also to secondperson gnomai.

26. Martin $(2009,123-24)$ draws attention to several characters in tragedy who fit uneasily into their social roles and also have difficulty using generalizations appropriately, suggesting that the misuse of gnomai is often emblematic of a more general lack of authority.

27. Briggs 1985,803 .

28. See Foley 1994, 89 on the importance of the audience's understanding of the typical use of proverbs in South Slavic epic. Abrahams and Babcock (1977, 417-18) note that proverbs when "re-situated" in literary contexts encourage a heightened level of scrutiny on the part of the audience.

29. Martin 2009, 119. 
degree of verbal authority over her listeners, do they accept that claim? The second set of questions concerns the gnomai themselves and their interpretation by both speaker and listener. For whom do the gnomic statements contain advice, and how are they interpreted by their hearers, both on- and offstage? The question of who should heed the advice embedded in a gnomic statement is more complicated than it may at first appear; just as the person of a proverb may vary depending on the circumstances, it is entirely possible for an ostensibly second- or third-person gnome to contain useful advice for its speaker. ${ }^{30}$ It is here in particular that the presence of the audience becomes important; from their privileged position, they can often see levels of meaning in dramatic generalizations that are hidden both from their onstage addressees and from the speaker herself. Although both Creon and the chorus in Antigone seem to take his opening generalizations about leadership as second- or third-person gnomai intended both for the listening chorus and the city as a whole, for example, the play's audience is in a position to see how well they apply to Creon himself.

In the following sections, I will be discussing the ways in which two very different Sophoclean characters rely on gnomic statements in order to establish and maintain their control over changing circumstances in their respective plays. I will begin with a discussion of Deianeira's generalizations in Trachiniae, arguing that, as her situation becomes increasingly precarious, Deianeira resorts to generalizations as a way to maintain some semblance of control. I will then move on to the Creon of Antigone, who, unlike Deianeira, typically generalizes from a position of power. Creon and Deianeira play very different roles in their respective plays, and they consequently use gnomic statements under different circumstances and to very different effect. For both, however, gnomic speech is a mark of character, and their particular use of gnomai provides a framework according to which the audience can gauge their changing ability to function in the different worlds of their two plays.

\section{GNomai Are “Good to Think With”: Deianeira Generalizes}

As many critics have noted, Trachiniae, perhaps even more than other plays of Sophocles, is a tragedy in which much supposed knowledge is later discovered to be false or, at least, misleading. ${ }^{31}$ Although Heracles" "late learning" plays a substantial part in his eventual destruction, it is Deianeira's evolving knowledge that is most visible to the audience over the course of the play. At each stage in her understanding, Deianeira generalizes about the world, and her generalizations often stand in counterpoint to other general statements on the human condition; in particular, the chorus' frequent gnomai, although calculated to support Deianeira in her trouble, are often at odds with Deianeira's assessment of her own situation. ${ }^{32}$ By correcting the generalizations of the chorus, Deianeira makes

30. Similarly, Lardinois $(2000,644)$ discusses "indirect second person gnomai," which ostensibly contain advice for the speaker or a third party, but at the same time allow the speaker to make a comment about the addressee.

31. See, among others, Whitman 1951, 103-21; Lawrence 1978; Kraus 1991. Heiden 1989 and 2012 present a more extreme version of this view.

32. Tragic choruses are prolific users of generalization. On the force of choral gnomai, Wolf $(1910,24)$ suggests that gnomai contribute to the solemnity of the tone of many choral odes; Gould $(1999,111)$ comments on 
a claim to be able to speak not only for herself, but also for others who might be in analogous positions. For much of the play, gnomic speech is one of few sources of certainty left to the increasingly desperate heroine, and when she finally loses her ability to generalize, her changing speech patterns signify the more general deterioration of her situation. ${ }^{33}$

Trachiniae opens with an extended speech from Deianeira, which begins with one of the most famous gnomic statements in the extant Sophoclean corpus. "It is an old saying among men," says Deianeira, "that you cannot learn the truth about a person's life, whether it was a good one or a bad one, before that person

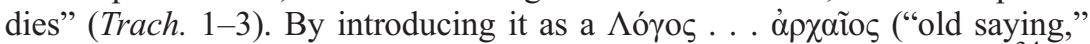
Trach. 1), Deianeira explicitly identifies her opening gnome as traditional. ${ }^{34}$ As her speech continues, however, Deianeira judges the traditional saying with which she began and finds it inadequate as an assessment of her own life. Moreover, Deianeira's handling of the play's first gnome - she presents it, puts it to the test, and then moves toward her own formulation of how life ought to be judgedprovides a model for the use of gnomic statements in processing events. ${ }^{35}$

When Deianeira presents her "ancient saying" only to reject it, commenting,

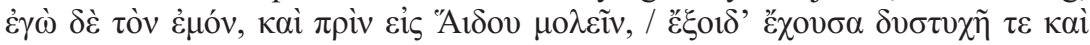
ßapúv ("but I know, even before I go down to Hades, that my own life is unfortunate to the extreme," Trach. 4-5), she at first suggests a rhetorical stance entirely at odds with the instinct to generalize about the human condition. ${ }^{36}$ Rather than accepting the wisdom put forth by earlier men and supposedly applicable to all, Deianeira offers instead details about her own life, which she claims is an exception to the rule. ${ }^{37}$ The highly individualized litany of suffering that follows-Deianeira does not suggest that all human life is unfortunate, but merely that her own has been - is enough to disprove the proverb with which she began her speech. ${ }^{38}$ Although Deianeira does not say so in so many words, her forceful denial of the applicability of the proverb to her own circumstances hints at the difficulty of finding a generalization that applies to all mortals.

By dismissing a piece of established wisdom, Deianeira places herself in a position of rhetorical authority by making an implicit claim that she knows more than the originators of the proverb or, at the very least, is better qualified to judge

the connection between choral gnomai and the collective memory of the group, while Calame (1999, 137) discusses the ability of the chorus to imbue the events of tragedy with a general force. On the collective voice of the chorus and its implications for choral authority, see, e.g., Burton 1980, 3-4; Goldhill 1996, 250-51; 2012, 8587; Calame 1999, 127-32; Rutherford 2012, 221; Gagné and Hopman 2013, 23-25.

33. Deianeira deploys gnomic wisdom on eleven occasions over the course of Trach.: 1-3, 92-93, 144-50, 296-97, 441-42, 452-54, 552-53, 596-97, 721-22, 725-26, and 729-30.

34. Easterling (1982, ad 1) notes Solon's advice to Croesus at Herodotus 1.32 and argues that Deianeira's proverb is linked to the wisdom of Solon; Deianeira predates Solon in mythological time, so it would be anachronistic to say that Sophocles' Deianeira is actually quoting Solon, but it is nevertheless likely that an Athenian audience would have been reminded of Solon.

35 . Kitzinger $(2012,113)$ notes that "the prologue introduces an idea which the action will elaborate and complicate"; I would argue that this statement is true in terms of Deianeira's rhetoric as well as the content of her opening speech.

36. Heiden $2012,136$.

37. Kitzinger 2012, 113.

38. Heiden $(1989,23)$ argues that Deianeira, by rejecting the proverb's doctrine of change, gives her own life a comforting appearance of stability, even if that stability is a matter of constant suffering. 
in her own case. As the play goes on, it becomes apparent that this initial attempt to assert her own authority by situating herself with respect to another statement is a typical rhetorical move on Deianeira's part. ${ }^{39}$ Despite her rejection of the play's first proverb, Deianeira does not give up on generalizations altogether, but instead uses them to comment on the appropriate course of action under the current circumstances. Although Deianeira often uses gnomai to assert her authority in the presence of those around her, her gnomic statements retain a strong firstperson emphasis; even when she is advising Hyllus or Lichas or the chorus, Deianeira's generalizations also reflect upon her own life and represent an attempt to retain control over her own circumstances.

After her firm rejection of the proverb in her opening lines, Deianeira's authority falters over the rest of the prologue. Deianeira does not know where Heracles is and is nearly ( $\sigma \chi \varepsilon \delta \delta$ ó, 43$)$ sure that he has suffered some misfortune, and both her inability to be sure and her need for the Nurse's advice emphasize her lack of control over her own life. ${ }^{40}$ Hyllus, when he arrives, knows more than Deianeira does about the fate of Heracles, and his apparent access to what is said about his father ( $\varphi \alpha \sigma i ́, 70 ; \dot{\omega} \varsigma \dot{\varepsilon} \gamma \dot{\omega} \kappa \lambda \hat{v} \omega, 72 ; \varphi \alpha \sigma i ́ v, 74)$ highlights Deianeira's relative lack of power. It is from this state of uncertain control that Deianeira begins to generalize on her own behalf, and her gnomic statements from the end of the prologue up until just before she sends the poisoned robe to Heracles serve to reclaim and consolidate some of her lost authority. When

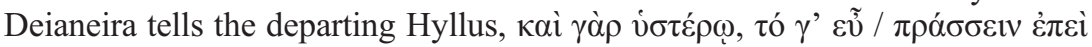

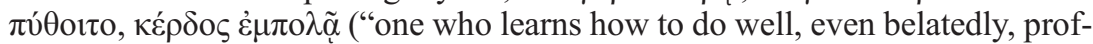
its," Trach. 92-93), her gnomic statement can be read in multiple ways. Most obviously, it acts as a second-person gnome, which emphasizes Deianeira's authority over her son and spurs Hyllus on his way, but it can also be read as a first-person statement, suggesting that Deianeira, despite her passivity up to this point, may yet regain control. ${ }^{41}$ Through its very ambiguity, Deianeira's generalization serves as a comment on the complicated status of her own authority at this point in the play.

Deianeira makes her first generalization after the conclusion of the prologue early in the first episode, in response to the comforting advice given by the chorus in the parodos. ${ }^{42}$ After saying that she hopes the chorus will never come to share her painful experience (Trach. 142-43), Deianeira offers an extended description of the innocence of youth and the changes in perception that occur along with marriage, suggesting that the chorus, as a group of still-unmarried girls, cannot understand the depth of her worry on behalf of her husband (Trach. 144-50):

39. Kraus $(1991,79)$ likewise draws attention to the extent to which Deianeira's rejection of the proverb is typical, although Kraus focuses on Deianeira's revision of a previously held truth in light of new information.

40. Hall 2009, 85 .

41. Easterling (1982, ad 92-93) notes a third level of meaning in Deianeira's gnome, in that "There is irony in these words for anyone who knows from the story what kind of news Hyllus will in fact hear."

42. Taplin $(1977,246)$ argues that although Hyllus and the Nurse exit at the end of the prologue, it is likely that Deianeira remains onstage. The chorus could theoretically be apostrophizing an absent Deianeira when it addresses her at 122 and 136, or Deianeira could reenter during the epode, but the length of her response to the chorus' consolation suggests that she has heard the entirety of the parodos. 


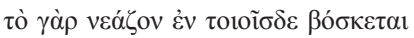

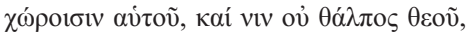

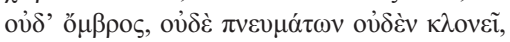

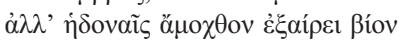

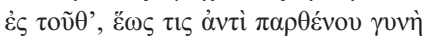

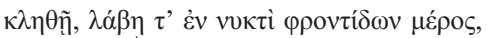

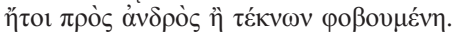

For youth is nourished in such places, and neither the heat of the sun, nor the rain, nor any wind disturbs it, but it carries out a life amidst pleasures, free from toil, until that point when she is called wife instead of maiden, and she receives her share of fears in the night, worrying about her husband or her children.

Despite its extraordinary length, Deianeira's comment to the chorus shares many of the key features of gnomic speech. In particular, as a self-contained statement about the way of the world, it suggests that Deianeira has a level of experience that the members of the chorus lack, and that she hopes they will never need. Even more than the literal content of her generalization about youth and age, Deianeira's implicit claim that she can make such a generalization draws attention to her position of authority over the chorus.

Although Deianeira's description of the innocence of youth can be read as a second-person gnome, predicated on Deianeira's superior authority and designed to convince the chorus not to offer opinions about matters in which it is inexperienced, its application in the context of the play is more complicated. Deianeira

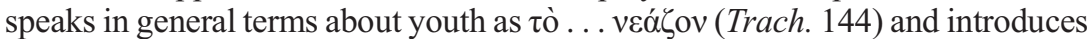
her comment about the transition to womanhood with the indefinite $\tau 15$ (Trach. 148), but what she presents to the chorus at this point is essentially a summary of her own life in general terms. ${ }^{43}$ Deianeira's account of the idyllic life of the unmarried girl has little in common with her earlier account of her girlhood fear of marriage, but her comment about the married woman's fears for her husband and children (Trach. 149-50) echoes her comment in the prologue that, since her

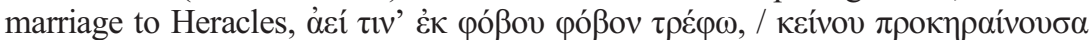
("always I nourish one fear after another in my anxiety for him," Trach. 29$30) .{ }^{44}$ Deianeira's generalization, although ostensibly for the benefit of the chorus, is thus in large part a first-person reflection on her own life. Deianeira's experience, which in the prologue was treated as an exception - albeit a negative one - to the general uncertainty of life, has become the pattern of all human experience. Although her future has been thrown into doubt by Heracles' continuing absence, Deianeira's ability to generalize from experience suggests that her place in the world has not slipped entirely out of her own control.

Later in the play, after Deianeira has seen the effect of the poison on the tuft of wool and resolved to die along with Heracles if the anointed robe should prove fatal to him, the contrast between her perspective and that of the chorus is thrown into sharp relief. Between the end of Deianeira's speech about the likely consequences of her actions and the entrance of Hyllus at 734, the chorus tries to

43. Wolf $(1910,21)$ sees the passage as a lament for Deianeira's own lost youth.

44. Easterling (1982, ad 149-50) notes the parallels between this passage and 27-30. See also Segal 1981, 84 on the contrast between Deianeira's description of generalized maidenhood and her own past. 
dissuade Deianeira from her resolution; it argues that the situation may not be hopeless, while Deianeira insists that nothing can save her now. ${ }^{45}$ Throughout the exchange, both parties speak almost entirely in gnomic statements; the chorus offers generalizations that encourage patience, fortitude, and continuing hope, and Deianeira replies with gnomai of her own focusing on the fact that the past cannot be changed. Despite their similar rhetorical choices, which might highlight a shared perspective, this final exchange of gnomai constitutes a breakdown in communication between Deianeira and the chorus. Although the chorus remains essentially supportive of Deianeira, their competing gnomai suggest incompatible views of the world, which point to divergent courses of action. ${ }^{46}$

The chorus at first responds to Deianeira's resolution to die with a gnome that echoes sentiments Deianeira herself has previously expressed: its comment,

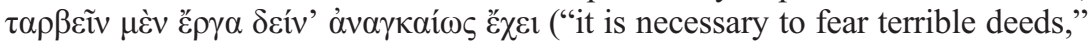
Trach. 723), refers most directly to the matter at hand, but also resonates with Deianeira's words of caution after she first heard of Heracles' sack of the city of Eurytus (Trach. 296-97). The chorus follows this first gnome, however, with a gnomic qualification, arguing that although a degree of fear is necessary, $\tau \dot{\eta} v \delta$ '

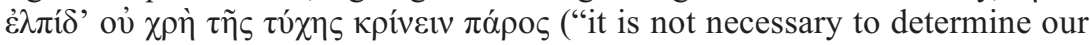
expectation before the event," Trach. 724). Its note of optimism is restrained, insofar as it uses $\dot{\varepsilon} \lambda \pi i$ í in the word's neutral sense to refer to any expectationgood or bad - of what is to come, but it nevertheless suggests that Deianeira's resolution to die is premature. ${ }^{47}$ As far as Deianeira is concerned, however, the choral gnome is inappropriate under the current circumstances; it is no longer "before the event," and she has no reason to hold out hope. ${ }^{48}$ She answers the

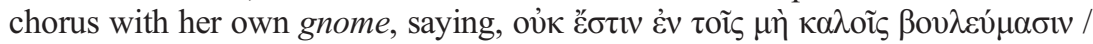

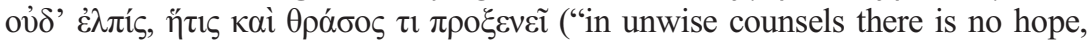
which can lend any courage," Trach. 725-26). Deianeira, unlike the chorus, uses in $\dot{\varepsilon} \lambda \pi$ í $\zeta$ a positive sense, and her interpretation of the word allows her to write off the chorus' gnomic statement as nothing but ill-considered optimism, delivered at a moment when she no longer has any use for words of comfort.

In its reply, the chorus once again seeks to frame its interaction with Deianeira in terms of common ground. It begins with an implicit concession to Deianeira; rather than saying that she will not suffer for her actions at all, the chorus offers a

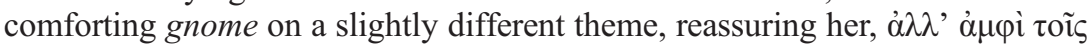

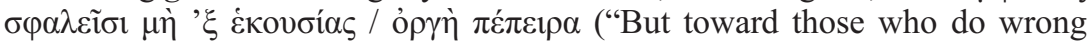
unwillingly, anger is softened," Trach. 727-28). Given that Deianeira earlier described herself as having acted $\alpha \dot{\alpha}$ ' $\dot{\lambda} \lambda \pi \dot{\delta} \delta \delta_{\varsigma} \kappa \alpha \lambda \tilde{\eta} \varsigma$ ("out of noble expectation," Trach. 667), the chorus has some reason to hope that she will accept its gnome.

45. McCall $(1972,153)$ sees the chorus' first comforting gnome as a statement of total disregard of Deianeira's resolution to die.

46. On the chorus' generally supportive position, Conacher $(1997,28)$ notes that after Deianeira first decides to send the robe, the chorus' reassurance is "all too easily available." See also McCall 1972, 153.

47. Both Jebb (1894) and Easterling (1982, ad 723-24) comment on the chorus' neutral use of غ̇ $\lambda \pi$ í here; see also Lawrence 1978, 298 on the chorus' interpretation of Deianeira's personal غ̇ $\lambda \pi$ íc.

48. Kraus $(1991,91)$ observes that up until Deianeira realizes $\mu \varepsilon \theta v$ $\sigma \tau \varepsilon \rho o v$ what she has done $(710)$, she has seen trouble in the past and vague hope in the future; even this vague hope is destroyed once she sees the effect of the poison on the wool. 
In Deianeira's answering criticism, however, she finds fault both with the particular reassurance offered by the chorus and with the presumption of its attempt to

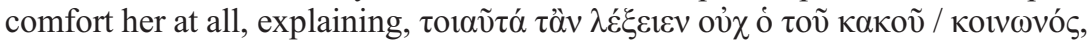

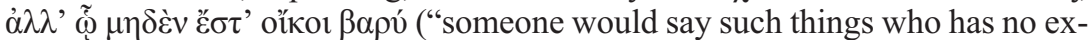
perience of misfortune, and for whom there is no trouble at home," Trach. 72930). The members of the chorus, who have throughout the play been Deianeira's supporters and confidantes, are suddenly placed at a great distance, reduced to the sort of person - who, as a generic concept, is masculine and singularwho has not experienced trouble and has no difficulties in his own affairs. Since,

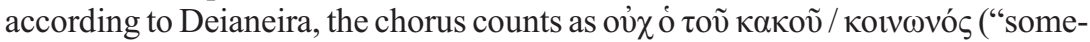
one who has no experience of misfortune," Trach. 729-30), it cannot hope to make valid generalizations about Deianeira's world.

After her final refusal to be reassured by the chorus, Deianeira speaks only five more lines, all of which are questions directed at Hyllus. Up to the entrance of Hyllus, Deianeira has been able to maintain a level of rhetorical control over her situation; her future in Heracles' household has grown increasingly uncertain, but she has nevertheless maintained the ability to integrate her own circumstances into her general view of the world. ${ }^{49}$ By speaking in gnomic statements, Deianeira has continued to assert her otherwise tenuous authority in the household; she may not be in control of events, but she can place them in a wider context, and is therefore in a position both to justify her own reactions to the present circumstances and to guide the responses of others. ${ }^{50}$ When Hyllus returns with news of the robe's effect on Heracles, Deianeira's ability to generalize ceases to matter. Hyllus is convinced of his mother's culpability, and, as such, he has no use for her either as an interpreter of events or as a source of advice. ${ }^{51}$ Throughout the play, Deianeira's main asset has been a belief in her own interpretive ability; now that Hyllus has seen the effect of the robe on Heracles, his understanding has outstripped his mother's, and there is nothing more that she can say to him. ${ }^{52}$

\section{GNOMAI In CONFlict: Authoritative Generalizations in ANTIGONE}

As Deianeira works to assert herself, she is never in direct conflict with her addressees; as Heracles' wife, moreover, she has a level of accepted authority over the chorus and other members of the household, who regularly address her as their mistress. ${ }^{53}$ The situation in Antigone, on the other hand, is different; although Creon's power is greater than Deianeira's, his role as the new ruler of Thebes is less firmly established than Deianeira's as the wife of Heracles, and, throughout most of the play, Creon treats criticism of his actions as a direct affront to his

49. Contra Bowman (1999, 344-46), who discounts Deianeira's powers of interpretation, arguing that the "female sexual power" that Deianeira tries to maintain by sending the robe is "the only power (via beauty) she or any woman has in the play" (p. 346).

50. Wiersma $(1984,51)$ identifies Deianeira's ability to process events as one of her defining features, describing her as a "perplexed but ultimately purposive personality."

51. Segal $(1981,97)$ notes, "Hyllus has his own logos to tell."

52. Lawrence $(1978,299)$ comments on Deianeira's questions as standing in contrast to Hyllus' direct knowledge.

53. Even Lichas, to whom Deianeira addresses several scathing generalizations, has acted only out of fear of upsetting his mistress. Deianeira is referred to as $\delta \varepsilon \dot{\varepsilon} \sigma \pi \mathrm{olv} \alpha$ or $\alpha$ $v \alpha \sigma \sigma \alpha$ at Trach. 49, 136, 180, 291, 409, 430, and 481. 
authority. ${ }^{54}$ From his own entrance until the exit of Teiresias, moreover, Creon has a series of confrontations with figures whose views are increasingly difficult for him to discount. All of these interactions are shaped by issues of authority, and it gradually becomes clear that, in the world of Antigone, authority is closely connected to control of general truths.

Although the matters at hand - the burial of Polyneices and Antigone's punishment for her role in it - are specific, Creon's confrontations tend to hinge on conflicting ideas about how the world should work, which are expressed on all sides through gnomic statements. ${ }^{55}$ Throughout the play, the gnomai of others are particularly threatening to Creon, and he, like Deianeira, often asserts his authority by replacing other characters' gnomai with generalizations of his own. Creon's generalizations, moreover, are for the most part concerned with the education of those around him; although his general statements can often be interpreted as first-person gnomai with implications for his own behavior, he typically presents them as second- and third-person advice intended both for his direct addressees and for the city as a whole. ${ }^{56}$ Creon suggests that it is his people, and not himself, who are in need of gnomic wisdom and that he is the one with the right to dispense such wisdom; over the course of the play, his ability to lead deteriorates along with his ability to generalize successfully for those in his power.

Creon's reliance on generalizations becomes apparent in his first speech, in which he lays out the principles according to which he believes that a man ought to rule. ${ }^{57}$ In speaking to the chorus, with whom he has no obvious reason to be at odds, Creon demonstrates many of the rhetorical strategies that will mark his subsequent interactions with more problematic figures. ${ }^{58}$ After an initial summary of the events that led him to assume the throne of Thebes (Ant. 162-74), Creon begins the body of his speech with a gnomic statement in which he claims (Ant. 175-77):

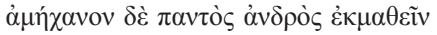

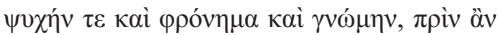

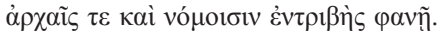

It is impossible to know fully the soul and the spirit and the opinion of a man, before he can be seen to be experienced in rule and law.

Although this statement applies to Creon as a new ruler, he says nothing about its particular application to his own present circumstances, suggesting instead

54. On the newness of Creon's rule, see Knox 1964, 84; Podlecki 1966, 360; Winnington-Ingram 1980, 122-24; Roisman 1996, 26; Cairns 2013, ix-xx.

55. Creon's tendency to generalize is frequently noted; Wolf $(1910,48)$ identifies Creon as the most prolific generalizer in Sophocles, while Kitzinger $(1976,144)$ comments on the number of generalities that Creon issues, identifying twenty-five in 350 lines of text. By my count, Creon issues generalizations, often in series, at Ant. 175-77, 189-90, 221-22, 295-303, 311-14, 473-79, 493-94, 520, 522, 661-62, [666-67], 672-76, 677$80,1045,1051,1055,1106$, and 1113-14; he also couches his own opinions in general terms at 178-83, 20710, 325-26, and 664-65. See also Podlecki 1966, 362; Foley 2001, 184-85.

56. Markantonatos $(1973,491)$ draws attention to a pattern of "unconciously suggestive utterances" delivered by Creon over the course of the play.

57. Knox $(1964,84)$ describes this speech as a kind of "inaugural address" to the people of Thebes.

58. Foley $(1996,60)$ notes that Creon does not adapt his mode of speaking to his audience. 
that it is generally applicable to the city as a whole, including the listening chorus. ${ }^{59}$ As he continues, however, Creon makes his personal stake in his generalizations clearer; although the man who does not follow good advice remains an indefinite ö $\sigma \iota \varsigma$ (Ant. 178), Creon's personal opinion of such a man is made

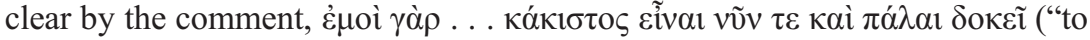
me he seems now and has for a long time seemed to be the worst of men," Ant.

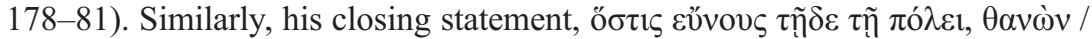

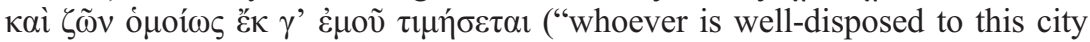
will be honored by me in death and in life," Ant. 209-10), would be gnomic but for the insertion of हैं $\gamma^{\prime} \dot{\varepsilon} \mu о \tilde{v}$ ("by me"). In the city that Creon rules, he is the driving force behind statements of general truth. ${ }^{60}$

Although the chorus acknowledges that Creon has the power to do what he wants in the city (Ant. 211-14), his absolute control over general truth slips as soon as he stops speaking. When Creon urges the chorus not to side with those who would attempt to disobey his edict, it replies with its own gnomic statement,

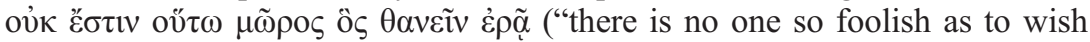

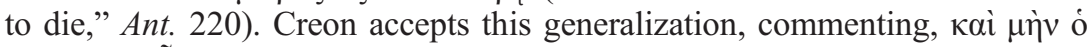

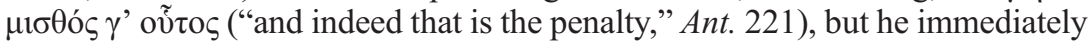
qualifies the chorus' statement with a counter-generalization that consolidates his

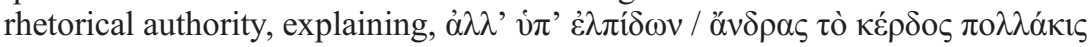
$\delta 1 \omega ́ \lambda \varepsilon \sigma \varepsilon v$ ("but beyond expectation profit has often destroyed men," Ant. 22122). The chorus may deserve some respect as a group of loyal citizens - Creon trusts the chorus enough to ask for its support - and it may be in a position to contribute usefully to a discussion of human tendencies, but Creon makes sure to have the last word. ${ }^{61}$

Both Creon's gnomic expression of the values he means to uphold as ruler of Thebes and his subsequent reliance on general statement to consolidate his authority are broadly accepted by the chorus; although the chorus is shaken by the guard's news that someone has buried Polyneices' body and suggest that the gods may have been involved (Ant. 278-79), it does not explicitly question Creon's authority, and it seems to accept the lesson on corruption that Creon offers in response to the guard's news. In subsequent scenes, however, Creon tries to impose his will on a series of figures whose relationships with him and his authority are more complicated than those of the chorus and the guard. As he interacts with Antigone, Haemon, and Teiresias, all three demonstrate their more general resistance to Creon's authority through their reluctance to accept his gnomic statements as a legitimate source of guidance. ${ }^{62}$

59. It is generally agreed that the sentiments expressed in Creon's opening speech, beginning with this gnome, are essentially acceptable, and only prove problematic when Creon takes them to extremes; Demosthenes (19.247) quoted Creon's description of good rule with approval, on which see Budelmann 2000, 76-77. Markantonatos $(1973,492)$ notes the irony of Creon's inability to see how his words apply to his own circumstances. See also Winnington-Ingram 1980, 123-24; Blundell 1989, 116-17; Sourvinou-Inwood 1989, 141-42; Griffith 1999, ad 162-210; Carter 2012, 117-18.

60. See Winnington-Ingram $(1980,123)$, who suggests that Creon's use of first-person singular pronouns may be "too insistent."

61. Segal $(1981,163)$ notes, "for [Creon], as for the Atreids in the Ajax, communication is one-way."

62. Griffith (1999, 23-24) suggests that in the original production Antigone, Haemon, and Teiresias would all most likely have been played by the same actor; their shared voice would thus perhaps have emphasized the serial nature of Creon's confrontations. 
Antigone's justification for disobeying the edict calls into question not only the particulars of Creon's presentation of himself as ruler, but also his right to generalize for the city that he rules. Antigone herself generalizes very little; when she explains the laws to which she does and does not feel herself to be subject, her statements, although broad, provide not so much a declaration of her own worldview as a rejection of the assumptions behind Creon's rule, and she thus begins her speech with ten lines of negated statements (Ant. 450-60) ${ }^{63} \mathrm{Al}-$ though she speaks in general terms about her willingness to die, asking, ö $\sigma \tau \iota \varsigma$

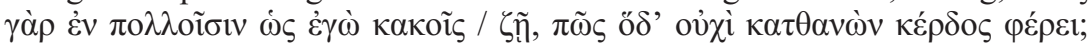
("Whoever lives amidst many troubles, as I do-how could he not benefit by

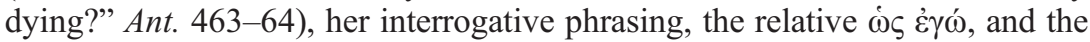
indicative $\varphi \varepsilon ́ p \varepsilon 1$ all suggest that Antigone's view on death is a personal one, which may not be shared by all people under all circumstances. Although she begins in general terms with an indefinite ö $\sigma \tau \iota \varsigma$, Antigone is by the end of her question speaking for herself from her own experiences, about which she, and not Creon, is the ultimate authority. ${ }^{64}$

Antigone, like Haemon and Teiresias in the following scenes, is troublesome to Creon because she disrupts his ideas about hierarchy. ${ }^{65}$ Both Creon's theory of government and the generalizations with which he defends it are concerned with the establishment and maintenance of order, and Antigone's refusal to be bound by hierarchical human laws is a threat to Creon's entire worldview. After

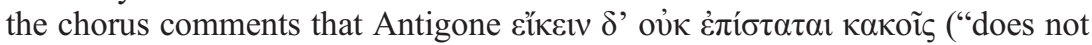
know how to yield to troubles," Ant. 472), Creon accepts its assessment of Antigone's stubbornness as a sign of deficient knowledge, beginning his response with $\alpha \lambda \lambda$ ' '̌ $\sigma \theta$ l ("but know," Ant. 473) and launching from there into a series of gnomic statements (Ant. 473-79), which, although they are delivered largely for Antigone's benefit, are addressed directly to the chorus. ${ }^{66}$ As he presents his gnomai, Creon emphasizes both the lessons that must be learned and his own

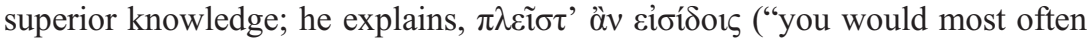
see," Ant. 476) the tendency of hardened iron to shatter, and that he himself knows (oĩ $\delta \alpha, A n t$. 477) the possibility of subduing a spirited horse with a small bit. By offering the chorus a string of ostensibly third-person gnomai that also function as second-person gnomai for Antigone's benefit, Creon can correct the listening Antigone without condescending to address her directly, thus putting her back in her rightful place and maintaining the role of ruler and educator of his subjects which he established in his opening speech.

Creon's authoritatively gnomic treatment of the problem of Antigone has a different background than his interaction with Haemon in the following episode; whereas Creon hints at a history of conflict with his characteristically insolent niece (Ant. 480-83), there is no such suggestion about his prior interactions with his son. ${ }^{67}$ When questioned about his response to Antigone's punishment,

63. Foley 1996, 52.

64. Foley 2001, 174.

65. Roisman 1996, 29.

66. Lauriola $(2007,396)$ notes Creon's criticism of Antigone's way of thinking.

67. Creon makes a similar suggestion about his prior relationship with his niece at 561-62 when he says that Antigone has been mad all her life; see Griffith 1999, ad 561-62 on the suggestion that there is a history of hostility between Antigone and Creon. 


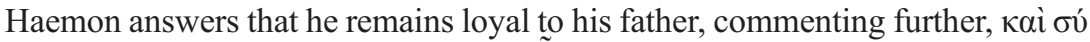

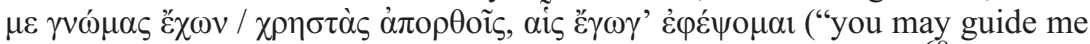
aright, with your good opinions, which I will follow," Ant. 635-36). ${ }^{68}$ It is in the context of Haemon's declaration that he is both obedient to his father's wishes and receptive to his father's tutelage that Creon sets forth his views on the situation. After capping Haemon's comment about the potential usefulness of his

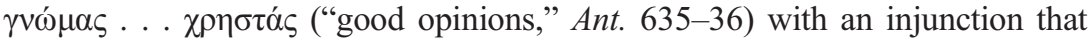
Haemon be ruled by $\gamma v \omega ́ \mu \eta \varsigma ~ \pi \alpha \tau \rho \omega ́ \alpha \varsigma$ ("paternal opinion") in all things (Ant. 639-40), Creon proceeds immediately to present Haemon with a list of the gnomai by which he ought to live.

As he works to educate his son, Creon's deployment of gnomic wisdom grows more complicated than it has been before. In previous scenes, Creon has suggested that his advice will benefit both its direct recipients and the city as a whole. With Haemon, however, Creon has a personal stake in the effectiveness of his own gnomai, and he opens with a series of third-person generalizations about fathers and children which, in their implicit guidance for Haemon, seem geared as much toward the maintenance of Creon's authority as toward the preservation of Haemon's general well-being. ${ }^{69}$ Creon's generalizations allow him to speak on his own behalf without doing so directly; after warning Haemon about the precedent

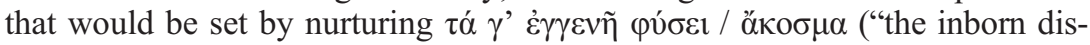
order in [my] kin," Ant. 659-60), Creon never mentions a personal connection with Antigone, and, in the last lines of his speech, Creon refers to her only in gen-

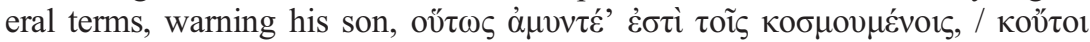

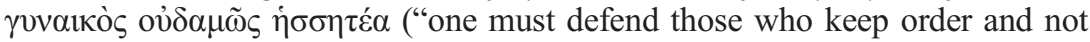
be defeated by a woman," Ant. 677-78).

In his response to Creon, Haemon picks up elements of his father's rhetoric and reshapes them in an attempt to convince him to change his plans. Haemon's advice to his father is largely gnomic, and, as such, it provides the play's first sustained challenge to Creon's status as the sole authoritative dispenser of general truth. ${ }^{70}$ Like his father, Haemon primarily directs his gnomai outward; after his first-person gnomic question about the value of parental success (Ant. 7034), Haemon, as Creon did with Antigone, moves into the role of educator as he begins to deliver second-person gnomai. No man, says Haemon, has a monopoly on speech and thought (Ant. 707-9), and therefore, even for a wise man, тò

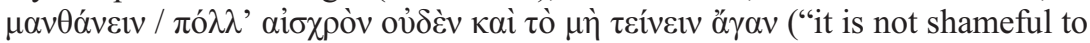
learn many things and not to strain excessively," Ant. 710-11). From this generalized suggestion that Creon stands in need of advice and that Haemon is in a position to give it to him, Haemon moves into a pair of gnomai reminiscent of Creon's earlier gnomai to Antigone about the dangers of not yielding under pressure (Ant. 712-17; cf. 473-76); Haemon's examples - trees that cannot bend

68. On the potential ambiguity of Haemon's opening lines, Griffith (1999, ad 635-38) notes, “ $\gamma v \omega ́ \mu \alpha \varsigma$ ع̈ $\chi \omega v$

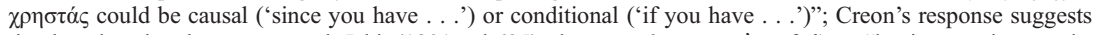
that he takes the phrase as causal. Jebb (1891, ad 635) glosses $\gamma v \omega ́ \mu \alpha \varsigma$. . d $\alpha$ o $\rho \theta 0$ oic as "having good counsels, thou settest them before me as rules," implying that Creon's gnomai for Haemon take on the status of law.

69. Blundell 1989, 120; Winnington-Ingram (1980, 125) comments, "Creon speaks, mostly, of his office, but thinks of himself." Griffith $(1998,67)$, however, notes that the each of the principles espoused by Creon in this speech "squares well with mainstream Greek domestic and democratic assumptions."

70. Foley 2001, 187. 
in the wind and men who refuse to slacken their sails - are different from his father's, but their overall message is much the same. ${ }^{71}$

Although both Creon and Haemon touch on the subject of Antigone's sentence, the final debate between father and son focuses largely on whether Haemon has any right to instruct Creon; when the chorus, implicitly acknowledging that Haemon's advice to his father might be thought to be inappropriate, advises Creon to listen if his son should say anything worthwhile (Ant. 724-25), Creon ignores the content of Haemon's speech altogether and asks, oi $\tau \eta \lambda \iota \kappa o i ́ \delta \varepsilon \kappa \alpha i$

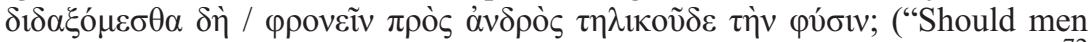
of my age be taught to know our place by a man of his age?" Ant. 726-27). ${ }^{72}$ From 730 until 745, the stichomythia between the two consists of questions from

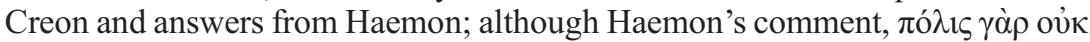

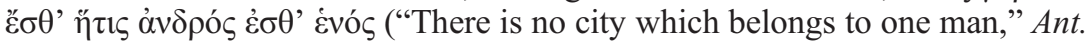
737 ), is the only real gnomic statement in the latter part of the scene, Creon's questions all deal with Haemon's right to offer advice to his father and king, advice which has already manifested itself in general statements. Haemon's reliance on generalization has marked him as very much his father's son; nevertheless, when Haemon trespasses on his father's rhetorical territory, Creon cannot see beyond Haemon's violation of social norms in order to judge his advice on its own terms. Communication between the two breaks down, and general statements on justice and civic leadership give way to increasingly personal insults. $^{73}$

When Teiresias enters two hundred lines later, Creon's interaction with the seer further complicates his presentation of himself as the arbiter of truth; while Creon can expect to be heeded by his son and his niece, Teiresias, as a seer, has a degree of automatic authority, even over Creon. When, having been asked what

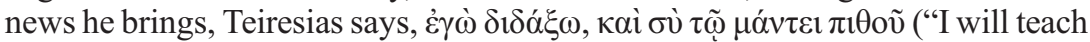
you, and you obey the seer," Ant. 992), he both emphasizes his own prophetic authority and takes on the didactic role which Creon has previously adopted in his interactions with others. ${ }^{74}$ As the scene continues, Teiresias continues to stress his own authority, ending his account with the injunction, $\tau \alpha \tilde{\tau} \tau$ ' oṽv,

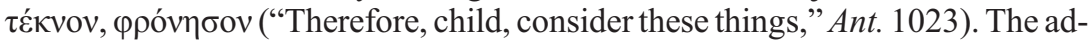
vice that follows is simple - give due respect to the dead - but it is embedded in a set of gnomai about the possibility of recovering from errors with the aid of good advice (Ant. 1023-32). By attempting to guide Creon through his current situation, Teiresias emphasizes his status as a teacher, and both his advice and its gnomic format suggest that Creon has much to learn.

Despite his initial willingness to vouch for the advice that Teiresias has given in the past (Ant. 993), Creon takes the seer's warning as a serious affront to his authority. Not only does he suggest that Teiresias, like all seers, must be corrupt

71. Griffith (1999, ad 712-18) argues that both Haemon's imagery and his language are gentler than Creon's. See also Kitzinger 1976, 137 n. 21.

72. Blundell 1989, 131.

73. Goldhill $(2012,62)$ questions the assertion from Griffith $(1999$, ad $726-65)$ that "Haemon emerges as the clear moral and verbal victor in the debate," noting that Haemon eventually resorts to verbal abuse. Hall $(2009,77-78)$ sees the exchange as a matter of failed deliberation on Creon's part.

74. Roisman 1996, 36. 
(Ant. 1033-36), but he also argues that he need not listen to Teiresias' warnings

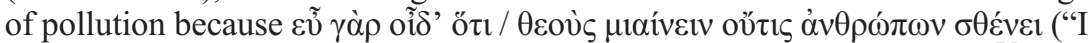
know well that no man has the power to defile the gods," Ant. 1043-44). ${ }^{75}$ This general statement, which Creon presents in terms of personal knowledge, and the following gnome about the fate of those who say shameful things for profit (Ant. 1045-47), allow Creon to suggest both that he will not take Teiresias' advice under the current circumstances and that he has no need for the seer's wisdom at all. As far as Creon is concerned, Teiresias is in no position to offer advice, and his general truths are therefore less valid than Creon's rival generalities.

After this initial gnomic assault on Teiresias' authority, Teiresias and Creon, like Creon and Haemon, quarrel not so much about Creon's current behavior as about who has the authority to state general truths. They trade gnomic statements and rhetorical questions relating to the flaws they see in each other; when

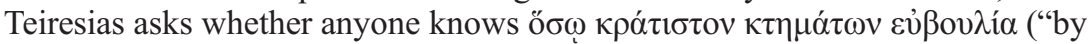
how much good counsel is the most valuable possession," Ant. 1050), Creon

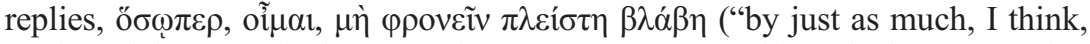
as thoughtlessness is the worst harm," Ant. 1051). Although they agree that

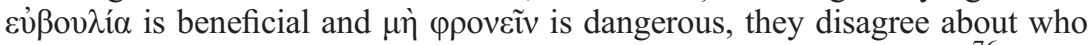
has the right to decide how the terms are used and to whom they apply. ${ }^{76}$ When

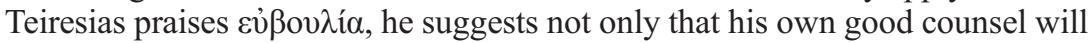
be beneficial to Creon, but also that it will reflect well on Creon if he is willing to be advised. Throughout the play, however, an unwillingness to be advised has been one of Creon's prominent features, and Creon responds as much to the fact that Teiresias has dared to advise him as to the content of his advice. ${ }^{77}$ Creon believes that he already knows how the world works, and he takes any attempt to influence his worldview as an insult to his dual role as ruler of Thebes and authoritative dispenser of truth to his subjects.

When, after the departure of Teiresias, Creon finally begins to acknowledge that the seer may in fact be correct, his change of heart is accompanied by a corresponding change in both his reception and his deployment of general truths. ${ }^{78}$ The magnitude of this change is signaled at 1105, when, in response to the chorus'

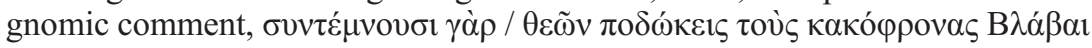
("the swift troubles sent by the gods cut off foolish men," Ant. 1103-4), Creon, rather than lashing out at the chorus for telling him a general truth, replies, o" $\mu$ or

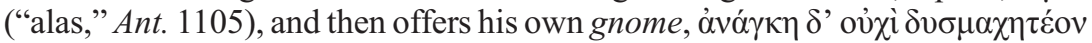
("one must not fight a losing battle with necessity," Ant. 1106), in agreement with the chorus' advice. For the first time in the play, rather than using gnomai to build up his own authority and belittle the knowledge of those who might seek

75. Griffith (1999, ad 1043-44) notes that Creon's claim sounds "hollow and unpersuasive" in the immediate aftermath of Teiresias' account. Oudemans and Lardinois $(1987,195)$ note that Creon is factually correct about the impossibility of polluting the gods, but that he ignores the likelihood that he may nonetheless pollute himself by dishonoring the gods.

76. Coray (1993, 193-94), having noted an emphasis on $\varepsilon \dot{\beta} \beta o v \lambda i \alpha$ and related words in the latter half of the play, comments, "Kreon erkennt schliesslich selbst seine $\delta v \sigma \beta o v \lambda i ́ \alpha 1$ (1269)." able."

77. Reinhardt $(1979,86)$ describes the Teiresias scene as 'a question of 'teaching a lesson' to the unteach-

78. Roisman (1996, 36-37) suggests that Creon is aware all along of the seer's superior authority, even though his desire to save face prevents him from yielding while Teiresias is still present. 
to change his mind, Creon begins to consider general statements - both his own

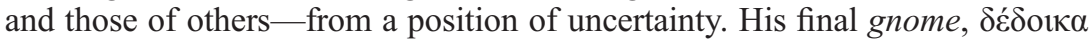

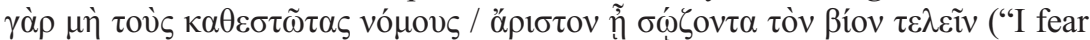
that it is best to live out one's life preserving the established laws," Ant. 1113-14), is phrased not as a matter of conviction but as a matter of misgiving. ${ }^{79}$ Having failed to force others to accept his assessment of the world, Creon must learn to live by a new kind of general truth.

\section{GENERALIZATIONS AND THE DYNAMICS OF AUTHORITY}

When Sophoclean characters generalize, the resulting statements can serve a number of different - if sometimes overlapping - purposes. On one level, gnomai delivered by characters onstage function much like proverbs or other generalizations outside of drama, inasmuch as the generalizations made by tragic characters typically have implications for the behavior of the speaker or her intended listener, and those who are on the receiving end of gnomic statements must decide whether to act in accordance with the gnomai delivered by fellow characters. Thus Haemon must decide whether to accept Creon's ideal of rulership and fatherhood, and Deianeira must decide whether to be heartened by the gnomic reassurances of the chorus of Trachiniae. At the same time, gnomic statements allow characters to project an image of themselves and their place in the world they inhabit. Successful interactions between characters depend in large part upon shared understanding, and in many cases, gnomic statements provide a context for testing the compatibility of the worldviews held by different figures. As Deianeira's relationship with the chorus and Creon's relationship with Haemon deteriorate, the faults in their relationships are highlighted by failures in gnomic communication.

The act of using gnomic statements to advise others entails making a claim to a level of authority, both inasmuch as advising others successfully depends on having the social status to make such advice palatable and inasmuch as generalizing requires a view of the world broad enough to make a gnomic statement applicable beyond its immediate context. ${ }^{80}$ Thus when Teiresias generalizes in Antigone about the tendency of humans to err and their ability to recover from past errors, both his prophetic ability and his history of offering sound advice suggest authority which extends beyond the present situation and supports his current generalizations. ${ }^{81}$ Other characters whose authority is not so well established also generalize, and when they do, they often use gnomai to bolster their own authority, both in their own eyes and in the eyes of those around them. In this way, Deianeira's generalizations on the plight of women and appropriate behavior under trying circumstances represent an attempt to assert control in a situation that is rapidly getting out of hand. Similarly, when Creon, whose authority is under threat from several sides, attacks Teiresias and his generalizations

79. Foley $(2001,187)$ notes that, as Creon changes his mind, "he recognizes at first only the validity of the traditional usages (1113-1114) that he rejected in Antigone's argument."

80. Searle $(1976,5)$ notes that the illocutionary force of a speech act designed to influence the behavior of someone else will depend on the relative status of speaker and listener.

81. Lardinois $(2006,223)$ comments on the characteristics shared by gnomic statement and prophecy. 
and offers his own gnomai to support his case, he not only rejects the prophet's advice, but also makes a broader claim for his own authority over Teiresias and over the city as a whole.

Generalizations, however, are a risky way of building and maintaining authority. When a speaker's generalizations are not accepted, not only does the speaker fail to bolster her own authority, but she may also open herself to criticism to which she would not otherwise have been vulnerable. Creon's use of gnomic statements in his attempt to guide Haemon's thoughts about Antigone backfires badly; over the course of the conversation between father and son,

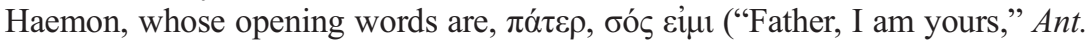
635), moves from a stated willingness accept his father's opinion and subordinate his desire for marriage to Creon's judgment (Ant. 635-38) to a promise

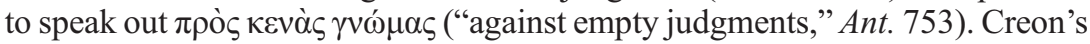
authority has been undercut not only by his stance on the Antigone issue but also by his assumption that his generalizations about the relationships between family, gender, and good governance should be accepted both by his son and by the city as a whole. Creon may have considerable power, both as ruler of Thebes and as Haemon's father, but, as Haemon suggests, his political and familial positions do not give him the authority to generalize for his son and his subjects if his opinions do not prove to be sound. ${ }^{82}$

Not only can characters jeopardize their authority by relying too heavily on generalizations, but they can also find it difficult to control the interpretation of their general statements. Most gnomai lend themselves to multiple interpretations, and they can therefore easily be applied to situations and people other than those intended by their speakers. ${ }^{83}$ When Creon generalizes to Antigone about the need to bend rather than cracking under pressure (Ant. 472-75), his warnings about the dangers of inflexibility apply so well to his own behavior that Haemon independently deploys a similar set of generalizations in his warning to his father in the third episode. ${ }^{84}$ Similarly, after Deianeira begins her prologue speech with a rejection of an ancient proverb, the interpretation of the proverb slips out of her control. Deianeira takes the proverb, as it is often taken, to refer to the foolishness of assuming that present happiness will last, and she rejects it on the grounds that she is already unhappy. As her situation worsens, however, it becomes apparent to the audience that Deianeira did not know how fortunate she really was at the beginning of the play. ${ }^{85}$ When the Nurse, at the conclusion of

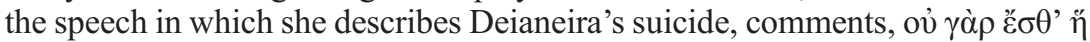

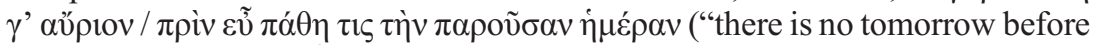
one gets through the present day successfully," Trach. 945-46), her echo of the

82. See n. 68 above on the possibility that Haemon's initial statement of willingness to be guided is only conditional.

83. Lardinois $2006,216$.

84. See discussion above on the similarity of the rhetoric employed by father and son; Haemon is not present for Creon's generalizations and cannot be suspected of taking direct inspiration from them, but the audience is likely to note the parallels between Haemon's gnomai and Creon's. Kitzinger (1976, 102-3) suggests that the metaphors that Creon employs in his generalizations about Antigone are inappropriate under the current circumstances.

85. On the irony of Deianeira's interpretation of the gnome, see, among others, Easterling 1968, 58; Lawrence 1978, 300; Kraus 1991, 76-77. 
proverb that she heard Deianeira reject at the beginning of the play highlights Deianeira's inability to understand her own position. ${ }^{86}$

When they turn to generalizations, then, both Deianeira and Creon make a kind of rhetorical gamble. On the one hand, they can both solidify their authority and suggest that their authority is socially acceptable; thus Creon in the first episode of Antigone can equate his rule over Thebes with the preservation of civic order, while Deianeira can frame her actions in terms of the behavior appropriate to a woman of noble birth. On the other hand, however, reliance on generalizations can alienate listeners who do not accept a speaker's right to generalize - as happens on both sides of the confrontation between Creon and Haemon-and poorly chosen gnomic statements can undercut the message that their speaker is trying to convey. As Deianeira works first to persuade Lichas to tell the truth,

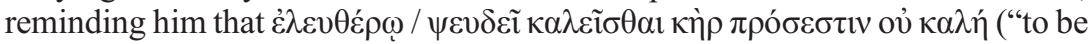
called a liar is an ignoble fate for a free man," Trach. 453-54), and then to per-

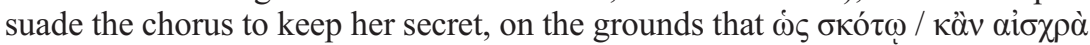

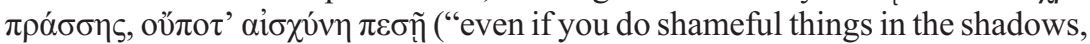
you will never fall into dishonor," Trach. 596-97), her generalizations express two very different ideas about honesty. Although both Lichas and the chorus are persuaded, the audience may take Deianeira's reliance on conflicting generalizations as a sign of her uncertain moral position.

Both Deianeira and Creon generalize at moments when their control over their respective situations is, for one reason or another, tenuous. Deianeira generalizes as a way to assert herself in the face of Hyllus, the chorus, and, later, Lichas, despite the fact that her position as Heracles' wife is increasingly insecure, while Creon generalizes first as a way to signal his intentions for his new rule and, later, when he feels that rule is being threatened ${ }^{87}$ Although the situations that they seek to control are very different, both characters are initially successful in their use of generalizations; Deianeira takes a degree of control over her circumstances and assures herself of the support of the chorus as she does so, while Creon's gnomic framing of his actions allows him to circumvent a potential initial round of objections to his treatment of Antigone.

In both plays, however, there comes a time when gnomic statements are insufficient for the needs of their speakers. Generalizations only work as intended when their hearers accept that the generalization in question is applicable to the current circumstances and that the person speaking in gnomai has the authority to generalize; over the course of their respective plays, both Deianeira and Creon lose that authority and cannot get it back. Creon's loss of authority occurs over the course of several encounters and is the subject of much onstage discussion; after Antigone rejects his rules in favor of the unwritten laws to which she chooses to adhere (Ant. 450-55), Haemon and Teiresias in turn assail both Creon's ability to speak for the whole city and his refusal to be advised by those around him. Deianeira's authority, which extends only to herself and some aspects of her

86. Kraus $(1991,94)$ notes the similarity between the Nurse's gnome and Deianeira's rejected proverb. See also Easterling 1982, ad 943-46; ad 1-48, Easterling notes that the Nurse is almost certainly present onstage to hear Deianeira's opening speech.

87. See n. 54 above on the newness of Creon's rule. 
household, is never so secure as Creon's - her ability to make domestic decisions is shown to be uncertain in the prologue, when it is the Nurse who suggests sending Hyllus in search of news - and it collapses all at once in her final encounter with Hyllus. When, at the conclusion of Hyllus' account, the chorus suggest that Deianeira confirms her own guilt by leaving in silence (Trach. 813-14),

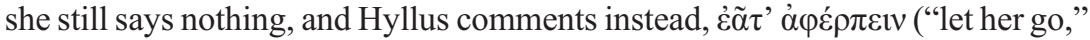
Trach. 815); having failed both in her attempt to win back Heracles and in her attempt to keep her actions secret, Deianeira implicitly cedes all authority to her son.

As Deianeira and Creon generalize their way through various personal, familial, and - in Creon's case - political difficulties, their reliance on general statements highlights their perception of how they fit into the worlds of their respective plays. Deianeira spends much of her play in a state of doubt, and her generalizations in moments of particular uncertainty allow her to reinforce her increasingly tenuous position in her own household. The authority she claims is strictly personal and domestic, and the majority of her generalizations, even those directed at others, can be taken as commentary on what a person in Deianeira's circumscribed position ought to do. Creon's gnomai, however, all rely on the assumption that Creon is - or ought to be - in a position of power over his addressees. So long as Creon remains certain of his own power, his generalizations allow him to shield himself from criticism and bolster his faltering authority over his family and over the city as a whole, but he loses his taste for generalization when he is forced to see that he has lost control. Just as Deianeira can no longer generalize to a Hyllus who has seen the effect of her actions, Creon's rhetoric breaks down in tandem with the collapse of his moral authority in Thebes.

University of Oxford

\section{LITERATURE CITED}

Abrahams, Roger D. 1972. Proverbs and Proverbial Expressions. In Folklore and Folklife: An Introduction, ed. Richard M. Dorson, 117-27. Chicago.

Abrahams, Roger D., and Barbara A. Babcock. 1977. The Literary Use of Proverbs. The Journal of American Folklore 90: 414-29.

Austin, J. L. 1975. How to Do Things with Words ${ }^{2}$. Ed. J. O. Urmson and Marina Sbisà. Oxford. Basso, Keith H. 1976. "Wise Words" of the Western Apache: Metaphor and Semantic Theory. In Meaning in Anthropology, ed. Keith H. Basso and Henry A. Selby, 93-121. Albuquerque.

Blundell, Mary Whitlock. 1989. Helping Friends and Harming Enemies: A Study in Sophocles and Greek Ethics. Cambridge.

Bowman, Laurel. 1999. Prophecy and Authority in the Trachiniai. AJP 120: 335-50.

Briggs, Charles L. 1985. The Pragmatics of Proverb Performance in New Mexican Spanish. American Anthropologist 87: 793-810.

Budelmann, Felix. 2000. The Language of Sophocles. Cambridge.

Burton, Reginald W. B. 1980. The Chorus in Sophocles' Tragedies. Oxford.

Cairns, Douglas. 2013. Introduction: Archaic Thought and Tragic Interpretation. In Tragedy and Archaic Greek Thought, ed. Douglas Cairns, ix-liv. Swansea. 
Calame, Claude. 1999. Performative Aspects of the Choral Voice in Greek Tragedy: Civic Identity in Performance. In Performance Culture and Athenian Democracy, ed. Simon Goldhill and Robin Osborne, 125-53. Cambridge.

Carter, David. 2012. Antigone. In Brill's Companion to Sophocles, ed. Andreas Markantonatos, 111-28. Leiden.

Conacher, D. J. 1997. Sophocles' Trachiniae: Some Observations. AJP 118: 21-34.

Coray, Marina. 1993. Wissen und Erkennen bei Sophokles. Basel.

Easterling, P. E. 1968. Sophocles' Trachinae. BICS 15: 58-69. , ed. 1982. Sophocles: "Trachiniae." Cambridge.

- 2009. Sophocles and the Wisdom of Silenus: A Reading of Oedipus at Colonus 12111248. In Antiphilesis, ed. Eleni Karamalengou and Eugenia Markrygianni, 161-70. Stuttgart.

Foley, Helene P. 1996. Antigone as Moral Agent. In Tragedy and the Tragic: Greek Theatre and Beyond, ed. Michael Silk, 49-73. Oxford.

- 2001. Female Acts in Greek Tragedy. Princeton, NJ.

Foley, John Miles. 1994. Proverbs and Proverbial Function in South Slavic and Comparative Epic. Proverbium 11: 77-92.

Gagné, Renaud, and Marianne G. Hopman. 2013. Introduction: The Chorus in the Middle. In Choral Mediations in Greek Tragedy, ed. Renaud Gagné and Marianne G. Hopman, 1-34. Cambridge.

Goldhill, Simon. 1996. Collectivity and Otherness - The Authority of the Tragic Chorus: Response to Gould. In Tragedy and the Tragic: Greek Theatre and Beyond, ed. Michael Silk, 244-56. Oxford.

. 2012. Sophocles and the Language of Tragedy. Oxford.

Gould, John. 1999. Myth, Memory, and the Chorus: “Tragic Rationality.” In From Myth to Reason? Studies in the Development of Greek Thought, ed. Richard Buxton, 107-16. Oxford.

Griffith, Mark. 1998. The King and the Eye: The Rule of the Father in Greek Tragedy. PCPS 44: $20-84$.

—, ed. 1999. Sophocles: “Antigone.” Cambridge.

Hall, Edith. 2009. Deianeira Deliberates: Precipitate Decision-Making and Trachiniae. In Sophocles and the Greek Tragic Tradition, ed. Simon Goldhill and Edith Hall, 69-96. Cambridge.

Heiden, Bruce. 1989. Tragic Rhetoric: An Interpretation of Sophocles' “Trachiniae.” New York.

- 2012. Trachiniae. In Brill's Companion to Sophocles, ed. Andreas Markantonatos, 12948. Leiden.

Housman, A. E. 1928. Fragment of a Greek Tragedy. The Yale Review 17: 414-16.

Jebb, Richard C., ed. 1891. Sophocles: The Plays and Fragments. Part 3, The "Antigone", Cambridge. - ed. 1894. Sophocles: The Plays and Fragments. Part 5, The "Trachiniae." Cambridge.

Kindstrand, Jan F. 1978. The Greek Concept of Proverbs. Eranos 76: 71-85.

Kitzinger, Margaret Rachel. 1976. Stylistic Methods of Characterization in Sophocles' Antigone. PhD diss., Stanford University.

- 2012. The Divided World of Sophocles' Women of Trachis. In A Companion to Sophocles, ed. Kirk Ormand, 111-25. Oxford.

Knox, Bernard M. W. 1964. The Heroic Temper: Studies in Sophoclean Tragedy. Berkeley, CA.

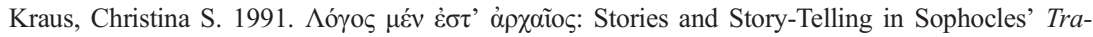
chiniae. TAPA 121: 75-98.

Lardinois, André. 1997. Modern Paroemiology and the Use of Gnomai in Homer's Iliad. CP 92: 213-34.

2000. Characterization through Gnomai in Homer's Iliad. Mnemosyne 53: 641-61.

2001. The Wisdom and Wit of Many: The Orality of Greek Proverbial Expressions. In Speaking Volumes: Orality and Literacy in the Greek and Roman World, ed. Janet Watson, 93-107. Leiden.

2006. The Polysemy of Gnomic Expressions and Ajax's Deception Speech. In Sophocles and the Greek Language, ed. Irene J. F. de Jong and Albert Rijksbaron, 213-23. Leiden. 
Lauriola, Rosanna. 2007. Wisdom and Foolishness: A Further Point in the Interpretation of Sophocles' Antigone. Hermes 135: 389-405.

Lawrence, Stuart E. 1978. The Dramatic Epistemology of Sophocles' Trachiniae. Phoenix 32: 288-304.

Markantonatos, G. 1973. Tragic Irony in the Antigone of Sophocles. Emerita 41: 491-97.

Martin, Richard P. 2009. Gnomes in Poems: Wisdom Performance on the Athenian Stage. In Antiphilesis, ed. Eleni Karamalengou and Eugenia Makrygianni, 116-27. Stuttgart.

McCall, Marsh. 1972. The Trachiniae: Structure, Function, and Heracles. AJP 93: 142-63.

Oudemans, T. C. W., and A. P. M. H. Lardinois. 1987. Tragic Ambiguity: Anthropology, Philosophy and Sophocles' "Antigone." Leiden.

Podlecki, Anthony J. 1966. Creon and Herodotus. TAPA 97: 359-71.

Reinhardt, Karl. 1979. Sophocles. Trans. Hazel Harvey and David Harvey. Oxford.

Roisman, Joseph. 1996. Creon's Roles and Personality in Sophocles' Antigone. Helios 23: 21-42.

Rutherford, R. B. 2012. Greek Tragic Style: Form, Language and Interpretation. Cambridge.

Searle, John R. 1969. Speech Acts: An Essay in the Philosophy of Language. Cambridge. . 1976. A Classification of Illocutionary Acts. Language in Society 5: 1-23.

Segal, Charles. 1981. Tragedy and Civilization: An Interpretation of Sophocles. Cambridge, MA.

Seitel, Peter. 1981. Proverbs: A Social Use of Metaphor. In The Wisdom of Many: Essays on the Proverb, ed. Wolfgang Mieder and Alan Dundes, 122-39. New York.

Slater, William J. 2000. Gnomology and Criticism. GRBS 41: 99-121.

Sourvinou-Inwood, Christiane. 1989. Assumptions and the Creation of Meaning: Reading Sophocles' Antigone. JHS 109: 134-48.

Taplin, Oliver. 1977. The Stagecraft of Aeschylus. Oxford.

Versnel, Henk S. 2011. Coping with the Gods. Leiden.

Whitman, Cedric H. 1951. Sophocles: A Study of Heroic Humanism. Cambridge, MA.

Wiersma, S. 1984. Women in Sophocles. Mnemosyne 37: 25-55.

Winnington-Ingram, R. P. 1980. Sophocles: An Interpretation. Cambridge.

Wolf, Eugen. 1910. Sentenz und Reflexion bei Sophokles. Tübingen. 